\title{
Inovasi Pelayanan Perpustakaan Keliling Sebagai Media Revolusi Mental di Jawa Barat
}

\author{
${ }^{1}$ Halimatus Sahdiyah Harahap, ${ }^{2}$ Bisyarah Rahmadhani, ${ }^{3}$ Afista Dwi Wardhani, \\ ${ }^{4}$ Muhammad Ghifar Hawary, ${ }^{5}$ Akbar Ardianto Rukmana
}

\author{
Politeknik STIA LAN Bandung, Indonesia; sahdiyahhalimatus@gmail.com \\ Politeknik STIA LAN Bandung, Indonesia; bisyarahmadhani@gmail.com \\ Politeknik STIA LAN Bandung, Indonesia; afistadwi123@gmail.com \\ Politeknik STIA LAN Bandung ghifarhawary26@gmail.com \\ Politeknik STIA LAN Bandung, Indonesia; akbarardianto29@gmail.com
}

\begin{abstract}
This study aims to determine the quality of mobile library service which is one of the innovative services in the field of literacy organized by the Government of West Java. Literacy Program is an effort made to prepare human resources to realize the internalization of a mental revolution to face the demographic bonuses in West Java. Consequently, the local government of West Java in collaboration with DISPUSIPDA released several literacy programs, one of the programs is mobile library which includes all districts and cities in West Java. The method in this study uses a descriptive method with a qualitative approach. The data collection technique is done through data that is directly observed in the field (observation) and through interviews. From the result of the study found that service is effective and able to run well. This mobile library service is expected to be able to foster public interest in reading, especially students in West Java to support the demographic bonus in which it shapes the character of students in accordance with the concept of mental revolution which includes work ethic, integrity and mutual cooperation.
\end{abstract}

Keywords: Local government, service innovation, literacy programs, mental revolutions, demographic bonuses.

\section{Pendahuluan}

Bonus demografi merupakan suatu istilah dalam ilmu kependudukan (demografi), baik ilmu demografi murni (pure demografi) maupun kajian kependudukan. Para ahli demografi memprediksikan pada tahun 2020 hingga 2030 nanti, Indonesia akan dihadiahi Bonus Demografi. Bonus Demografi yang dimaksud yaitu ketika negara Indonesia memiliki jumlah penduduk usia muda/produktif dengan jumlah yang melimpah, yaitu sekitar $2 / 3$ dari jumlah penduduk keseluruhan (Umar, 2018). Bonus demografi juga harus diiringi dengan pendidikan karakter untuk membangun revolusi mental di kalangan generasi muda. Istilah revolusi mental pada awalnya masih dalam tataran konsep dan belum jelas arahnya.

Namun, istilah tersebut menjadi menarik karena pasangan Jokowi-JK dapat memenangkan pemilihan Presiden Republik Indonesia periode 2014-2019. Istilah revolusi mental akhirnya juga menjadi salah satu prioritas program pembangunan masa pemerintahan Jokowi-JK, di samping program kemandirian bangsa dan kemaritiman. Istilah revolusi mental dipakai Jokowi berdasarkan latar belakang pengalaman dan hasil pengamatannya bahwa Pemerintahan Republik Indonesia pasca reformasi selama 16 tahun, dan telah ganti empat kali presiden, yaitu era Habibi, Gus Dur, Megawati, dan SBY, di samping telah mencapai berbagai prestasi, antara lain di bidang ekonomi, pendidikan, dan demokrasi. Akan tetapi, di sisi lain masyarakat Indonesia banyak yang mengalami ketidakpuasan dan kegalauan di berbagai bidang. Di manamana terjadi demonstrasi, perkelaian antar pelajar, perkelaian antar mahasiswa, perkelaian antar kelompok, dan antar masyarakat. (Salam, 2019). 
Revolusi mental merupakan suatu gerakan seluruh masyarakat baik pemerintah atau rakyat dengan cara yang cepat untuk mengangkat kembali nilai-nilai strategi yang diperlukan oleh bangsa dan negara sehingga dapat memenangkan persaingan di era globalisasi (Mulyasa, 2015). Revolusi mental berfungsi mengubah cara pandang, pikiran, sikap dan perilaku yang berorientasi pada kemajuan dan kemodernan, menjadi bangsa besar dan mampu berkompetisi dengan bangsa-bangsa lain di dunia. Perlunya revolusi mental karena penyakit seperti emosi/mental/jiwa akan berdampak pada individu berupa malasnya seseorang menggunakan bahasa daerah dan tidak mempunyai karakter. Dampaknya akan menular kepada masyarakat yang ditandai dengan bangsa yang lemah dan menjadi tidak bermartabat. (Salam, 2019)

Salah satu upaya untuk menginternalisasi revolusi mental adalah melalui peningkatan kesadaran literasi masyarakat. Pemerintah sedang menggencar-gencarkan program literasi karena Indonesia dianggap belum gemar dalam membaca. UNESCO mencatat indeks minat baca di Indonesia baru mencapai 0,001. Artinya dari 1000 orang, hanya 1 orang yang mempunyai minat baca. Rata-rata orang Indonesia hanya membaca buku 3-4 kali per minggu, dengan durasi waktu membaca per hari 30-59 menit (Kompas, 26 Maret 2018). Riset bertajuk World's Most Literate Nations Ranked yang dilakukan oleh Central Connecticut State University (CCSU) mengumumkan bahwa Indonesia berada pada peringkat 62 dari 70 negara. Artinya Indonesia sangat darurat akan minat baca (Detiknews, 05 Januari 2019).

Revolusi mental yang sebelumnya sudah ada pasa saat pemerintahan Bung Karno digaungkan kembali oleh Presiden Republik Indonesia, Joko Widodo untuk mengangkat kembali karakter bangsa yang telah mengalami kemerosotan dengan secepat-cepatnya dan bersama-sama (revolusioner). Karena itu revolusi mental harus digerakkan dan didukung oleh suatu konsorsium yang terdiri dari para tokoh nasional (birokrasi pemerintah, dunia usaha, tokoh agama, akademisi, seniman dan budayawan). Nilai-nilai yang terkandung di dalam revolusi mental, yakni:

a. Integritas

Integritas sebagai nilai yang mendasar dalam diri seseorang, hal ini berkaitan dengan sifat jujur, dipercaya, berkarakter serta bertanggung jawab.

b. Etos kerja

Sikap yang muncul atas kehendak dan kesadaran sendiri yang didasari oleh sistem orientasi nilai budaya terhadap kerja. Etos kerja ini berkaitan dengan daya saing, inovatif dan kreatif.

c. Gotong royong. Nilai gotong royong merupakan nilai yang lahir dari cerminan hidup masayarakat di Indonesia. Hal ini jelas tercermin dari pengelaman dari Pancasila sila ke-5, yang berorientasikan kepada kerjasama, solidaritas dan kemaslahatan.

Dapat disimpulkan bahwa pelayanan perpustakaan keliling merupakan suatu inovasi pelayanan yang bertujuan untuk mewujudkan revolusi mental dengan meningkatkan minat baca di Jawa Barat. Dengan meningkatnya minat baca diharapkan nilai-nilai yang ada dalam revolusi mental meliputi integritas, etos kerja dan gotong royong dapat tertanam dalam diri setiap generasi yang akan datang demi menghadapi bonus demografi.

Menurut Parasuraman dalam Lupiyoadi \& Hamdani (2006) terdapat 5 dimensi dalam mengukur kualitas pelayanan yang disebut SERVQUAL. Dimensi ini akan menentukan apakah pelayanan yang diberikan telah memenuhi standar, telah mencapai tujuan serta mengukur kesenjangan dari pelayanan yang diberikan dengan yang diharapkan oleh penerima layanan. Selain itu, guna untuk menemukan solusi dari masalah yang ada terkait pelayanan itu sendiri. Dimensi pelayanan tersebut meliputi: 
a) Tangibels, yaitu merupakan bukti fisik dari layanan itu sendiri. Hal ini menunjukkan ada nya sarana dan prasarana yang bersifat visual dan bertujuan untuk memberikan eksistensi kepada pihak eksternal. Hal ini tidak hanya mencakup fasilitas fisik (Gedung, Gudang dan transportasi) serta teknologi (peralatan dan perlengkapan yang dipergunakan), namun bagaimana pegawai atau pihak penyelenggara layanan berpakaian juga merupakan indikasi dari dimensi Tangibels ini.

b) Reliability, atau yang disebut dengan keandalan yaitu kemampuan penyelenggara memberikan pelayanan sesuai yang dijanjikan secara akurat dan terpercaya. Hal ini berkiatan dengan waktu layanan yang jelas, pelayanan tanpa kesalahan, serta sikap simpatik.

c) Responsiveness, merupakan suatu kemauan yang berhubungan dengan daya tangkap untuk membantu dan memberikan pelayanan yang cepat (responsive) dan tepat kepada pelanggan, seperti menyampaikan informasi yang jelas, mampu menjawab segala pertanyaan dari pelanggan terkait pelayanan yang diberikan. Dengan demikian, hal ini akan mempengaruhi jumlah konsumen yang menggunakan layanan tersebut.

d) Assurance, atau jaminan dan kepastian yaitu pengetahuan, kesopan santunan, kemampuan para pegawai yang sesuai dengan kompetensi nya guna untuk menumbuhkan rasa percaya pelanggan kepada pemenrintah. Selain itu pelayanan harus memberikan rasa aman kepada pelanggan.

e) Empathy, yaitu memberikan perhatian yang tulus baik bersifat individual atau kelompok yang diberikan kepada pelanggan dengan berupaya memahami keinginan konsumen, Pemerintah sebagai contoh pemberi layanan diharapkan memiliki suatu pengertian dan pengetahuan tentang pelanggan, memahami kebutuhan pelanggan secara spesifik, Dimensi empathy terdiri dari tiga sub dimensi, yaitu:

1) Access (Akses) berhubungan dengan kemudahan mendapatkan akses layanan.

2) Communication (Komunikasi) Kemampuan pihak penyedia jasa dalam menggunakan bahasa yang mudah dimengerti pelanggan serta informasi yang singkat dan jelas.

3) Understanding Customer (Mengerti Pelanggan) Pihak pemberi layanan berusaha untuk memenuhi keperluan pelanggan.

Di dalam Pelayanan juga harus menyesuaikan dengan tantangan zaman, karena hal ini akan berdampak kepada banyak nya penggunaan pada layanan tersebut, maka dengan kata lain diperlukannya inovasi di dalam suatu layanan. Undang-Undang No. 35 Tahun 2009 tentang Pelayanan Publik mendefinisikan pelayanan publik yaitu kegiatan atau rangkaian kegiatan dalam rangka pemenuhan kebutuhan pelayanan sesuai dengan peraturan perundang-undangan bagi setiap warga negara dan penduduk atas barang, jasa dan/ata pelayanan administratif yang disediakan oleh penyelenggara publik. Jadi pelayanan publik ini sifatnya menyeluruh dan dapat dirasakan oleh semua warga negara. Pelayanan publik ini harus bersifat adil tanpa memandang bulu. Pelayanan yang diberikan harus sesuai dengan Standar Operasional Prosedur (SOP) yang ada di peraturan perundang-undangan.

Dalam memberikan pelayanan kepada masyarakat, sangat dibutuhkan budaya inovasi dan kreativitas dalam sebuah organisasi atau lembaga publik yang merupakan penyedia pelayanan. Pengembangan inovasi sesuai dengan kebutuhan masyarakat dan penggunaan instrument pelayanan dalam rangka memberikan pelayanan terbaik. Inovasi dan kreativitas pelayanan publik dapat mempermudah dan mempercepat pelayanan yang diberikan. Jadi, dalam sebuah pelayanan sangat penting adanya sebuah inovasi agar pelayanan yang diberikan tidak terlalu tradisional dan monoton dan itulah tugas pemerintah untuk membuat sebuah inovasi pelayanan. 
Sebagaimana inovasi merupakan suatu gagasan yang sifatnya baru dan menggantikan cara yang lama atau mengadaptasi dari cara yang lama namun terdapat perubahan yang signifikan didalamnya. Artinya inovasi tidak selalu menggantikan yang lama, namun di dalam nya terdapat perubahan-perubahan. Pada penelitian ini akan menggunakan teori dari Parasuraman yang disebut dengan SERVQUAL, dimana akan mengetahui tingkat kualitas dari pelayanan yang diberikan pemerintah khususnya pada pelayanan perpustakaan keliling dalam mendukung internalisasi revolusi mental di Jawa Barat. Selain itu, untuk menghadapai bonus demografi di Jawa Barat dan menghasilkan SDM khususnya pelajar yang berdaya saing, berkarakter sesuai dengan revolusi mental diharapkan agar tujuan dari pelayanan perpustakaan keliling yang telah dikeluarkan dapat berjalan dengan efektif. Tidak hanya di Jawa Barat saja, apabila pelayanan perpustakaan keliling serta inovasi terkait program tersebut dinilai efektif, maka program ini diharapkan dapat di adaptasi oleh daerah-daerah yang ada di Indonesia.

Untuk mendukung tercapainya revolusi mental di kalangan pelajar, Pemerintah Provinsi Jawa Barat khususnya Dinas Perpustakaan dan Kearsipan Daerah Provinsi Jawa Barat membuat beberapa inovasi pelayanan di bidang literasi, inovasi tersebut yaitu pelayanan perpustakaan keliling, KOLECER (Kotak Literasi Cerdas), CANDIL (Maca Dina Digital), Bunda Literasi, WJLRC (West Java Leader's Reading Challenge), dan lainnya. Programprogram tersebut dibentuk guna menumbuhkan minat baca di kalangan generasi muda khususnya pelajar yang akan merasakan dan menghadapi Bonus Demografi. Program literasi yang lebih ditekankan disini yaitu pelayanan perpustakaan keliling yang sudah berjalan bertahun-tahun di Jawa Barat.

Pelayanan perpustakaan keliling sudah mengunjungi daerah-daerah di kota maupun di kabupaten di Jawa Barat. Hal yang telah dipaparkan tersebut melatar belakangi peneliti untuk melakukan penelitian berkenaan dengan inovasi pelayanan program literasi yaitu pelayanan perpustakaan keliling di Jawa Barat dalam usaha pengoptimalan kualitas membaca di Jawa Barat untuk menciptakan SDM yang berkualitas. Dari kondisi yang telah dijelaskan, maka peneliti tertarik mengangkat judul penelitian tentang inovasi pelayanan perpustakaan keliling sebagai media revolusi mental di Jawa Barat. Dengan demikian, penelitian ini bertujuan untuk menganalisis inovasi pelayanan perpustakaan keliling sebagai media revolusi mental di Jawa Barat.

\section{Metode Penelitian}

Metode penelitian yang digunakan dalam penelitian ini adalah metode kualitatif, suatu metode yang bertujuan untuk untuk menggambarkan, meringkaskan berbagai kondisi, berbagai situasi, atau berbagai fenomena realitas sosial yang ada di masyarakat yang diperoleh dari perspektif pelaku yang diteliti (informan) tanpa adanya pengurangan atau penambahan seperti yang terjadi dalam optimalisasi pelayanan perpustakaan keliling di Provinsi Jawa Barat. Lokus penelitian ini adalah di wilayah Pemerintah Provinsi Jawa Barat dan Sekolah Dasar (SD), Sekolah Menengah Pertama (SMP), dan Sekolah Menengah Atas (SMA) di Kota Bandung. Dengan menggunakan teknik analisis kualitatif dihasilkan suatu temuan atau hasil penelitian yang akan menjawab pertanyaan penelitian yang diajukan. Subjek dari penelitian ini adalah para pelajar di lingkungan Kota Bandung/Jawa Barat. Ruang lingkup kajian penelitian ini meliputi dua aspek baik yang bersifat internal yaitu berupa informasi yang diterima dari pelajar di setiap tingkat sekolah dan dinasdinas terkait ataupun yang bersifat eksternal yaitu diperoleh dari apa yang dilihat langsung melalui obeservasi di lingkungan Pemerintah Provinsi Jawa Barat. 
Teknik pengambilan data dilakukan melalui data yang langsung diamati di lapangan (observasi) dan melalui wawancara snowball meliputi fakta-fakta atau informasi tentang partisipasi pelajar dan pihak-pihak yang terlibat serta fasilitas yang diberikan oleh Pemerintah di Provinsi Jawa Barat guna mendukung pelayanan perpustakaan keliling di Jawa Barat. Wawancara ini akan dilakukan secara semiterstruktur agar didapati data dan informasi yang sebenarnya dengan mengunakan pedoman wawancara yang disusun oleh peneliti dengan menyesuaikan kebutuhan data dan informasi yang ingin diperoleh. Informan wawancara adalah Pegawai Bagian Dinas Perpustakaan dan Kearsipan Daerah, Dinas Pendidikan Provinsi Jawa Barat, sekolah-sekolah mulai dari SD, SMP dan SMA, serta para pelajar.

Bahan dan alat yang digunakan peneliti yaitu pedoman wawancara yang mengacu pada konteks penelitian yakni pelayanan perpustakaan keliling. Dengan wawancara, peneliti berupaya mendapatkan informasi dengan bertatap muka secara fisik. Prosedur pengambilan data dimulai dengan cara mencari sumber yang relevan dengan judul penelitian agar mempermudah tim peneliti dalam memperdalam penelitian. Dengan menentukan unit analisis yang kompeten di bidangnya dan dapat menjawab segala pertanyaan yang diajukan oleh tim peneliti. Informasi dilengkapi dengan observasi langsung di lokasi yang dilakukan oleh tim peneliti. Adapun instrumen yang digunakan berupa panduan wawancara sebagai berikut.

1) Sejarah dan gambaran umum Program Literasi inovasi pelayanan perpustakaan keliling

2) Tujuan dan manfaat penerapan pelayanan perpustakaan keliling terhadap revolusi mental di Jawa Barat

3) Daya tanggap dan antusiasme pelajar terhadap program ini

4) Kualitas pelayanan dari perpustakaan keliling

5) Proses pelaksanaan program sampai sejauh ini

6) Peran dari pelayanan perpustakaan keliling untuk revolusi mental di Jawa Barat

7) Tantangan pelayanan perpustakaan keliling dalam menghadapi perubahan yang diinginkan

8) Seberapa banyak fasilitas yang disediakan di perpustakaan keliling untuk pelajar

9) Bentuk keseriusan penegakan pelayanan perpustakaan keliling dalam meningkatkan minat baca

10) Apakah ada tim khusus yang dibentuk untuk mengawal pelayanan perpustakaan keliling

Menurut Miles dan Huberman (1984), kegiatan analisis data terdiri dari empat alur kegiatan, yaitu melakukan pengelompokkan data, reduksi data, penyajian (display) data dan penarikan kesimpulan/verifikasi. Kegiatan tersebut sebagai sesuatu yang saling menjalin merupakan proses siklus dan interaksi pada saat sebelum, selama dan sesudah pengumpulan data dalam bentuk sejajar yang membangun wawasan umum yang disebut analisis. Krueger (1994) menyatakan beberapa hal yang perlu dipertimbangkan dalam analisis antara lain; pertimbangkan kata-kata yang digunakan oleh seluruh responden, mempertimbangkan konteks bahasan, mempertimbangkan respons dan temukan ide besar dan diskusi. (Herdiansyah, 2013).

Analisis fenomena dan masalah terkait pelayanan perpustakaan keliling menggunakan teori pelayanan Parasuraman yang memiliki 5 dimensi dalam mengukur pelayanan yang berkualitas, dimensi tersebut yaitu tangibles,reliability, responsiveness, assurance dan empathy. Teori tersebut akan digunakan penulis sebagai pedoman dalam menganalisis data 
penelitian yang didapat selama penelitian berlangsung, sehingga hasil penelitian dapat teruji dan menghasilkan kesimpulan yang ilmiah.

\section{Hasil Dan Pembahasan}

Program literasi sudah digaungkan sejak tahun 2015, setelah adanya Peraturan Kemendikbud No.23 Tahun 2015 tentang Penumbuhan Budi Pekerti yang menyatakan bahwa sekolah hendaknya memfasilitasi secara optimal agar siswa bisa menemukan dan mengembangkan potensinya, salah satunya adalah dengan kegiatan wajib menggunakan 15 menit untuk membaca buku selain buku mata pelajaran sebelum memulai pembelajaran. Di Jawa Barat Pembudayaan gemar membaca sendiri sudah ada dalam Peraturan daerah Provinsi Jawa Barat No 17 Tahun 2011. Tahun 2015.

Gerakan literasi mulai memberikan titik terang yang dimana dengan adanya MoU Sister Coorperation Pemerintah Provninsi Jawa Barat dengan Australia Selatan dalam berbagai bidang pembangunan, termasuk kerjasama lebih lanjut dalam bidang pendidikan salah satunya program literasi ini sendiri. Sesuai dengan Bab IV Pengelolaan dan Pengembangan Perpustakaan Pasal 10 paragraf 2 Peraturan Daerah Provinsi Jawa Barat yang menyebutkan Pemerintah Daerah dan Pemerintah Kabupaten/Kota melaksanakan pelayanan perpustakaan keliling di wilayah yang belum terjangkau oleh layanan perpustakaan menetap dan pada Pasal 21 paragraf 7 mengenai Perpustakaan Keliling disebutkan juga bahwa (1) Perpustakaan Keliling dilaksanakan oleh Perpustakaan Daerah dan Perpustakaan Kabupaten/Kota untuk melayani masyarakat yang sulit dijangkau oleh pelayanan perpustakaan menetap. (2) Pemerintah Daerah dan Pemerintah Kabupaten/Kota menyediakan biaya operasional Perpustakaan Keliling.

Perpustakaan keliling/Pusling adalah salah satu kegiatan menghadirkan Mobile Unit perpustakaan keliling yang memberikan layanan membaca dibeberapa titik layanan guna mensukeskan program budaya baca masyarakat juga Gerakan Litersi Sekolah (GLS). Dengan adanya perpustakaan keliling ini memungkinkan penduduk yang tinggal jauh dari perpustakaan umum dapat memanfaatkan jasa yang diberikan oleh perpustakaan umum. Sekolah atau instansi yang belum mempunyai perpustakaan yang menetap bisa memperoleh jasa layanan dari perpustakaan keliling (Disarsipus Kuningan: 2018).

Maka perpustakaan keliling merupakan salah satu program pengelolaan dan pengembangan perpustakaan yang tujuannya untuk menyediakan pelayanan perpustakaan kepada masyarakat secara cepat dan tepat. Selain itu PUSLING juga dicanangkan guna untuk meningkatkan minat baca khususnya bagi pelajar serta dari membaca dapat membentuk karakter integritas, etos kerja dan gotong royong sesuai konsep revolusi mental.

\section{Pelaksanaan Pelayanan Perpustakaan Keliling di Jawa Barat dan Kualita Pelayanannya}

Dinas Perpustakaan dan Kaersipan Daerah (Dispusipda) tak hentihentinya melakukan inovasi di bidang perpustakaan guna meningkatkan minat baca masyarakat khususnya para pelajar di Jawa Barat. Dispusipda Jawa Barat membuat inovasi layanan jemput bola yaitu layanan perpustakaan keliling yang mengunjungi daerah-daerah di Jawa Barat. Layanan perpustakaan keliling ini sebenarnya sudah lama dilakukan oleh Dispusipda Jawa Barat yakni pada tahun 2005, tetapi pada saat itu masih banyak masyarakat khususnya pelajar yang belum merasakan layanan perpustakaan keliling. Tahun demi tahun perpustakaan keliling semakin diminati oleh masyarakat. Layanan perpustakaan keliling pada tahun 2019 sudah ada 14 titik layanan, layanannya dilakukan di Kab. Ciamis, Purwakarta, Pangandaran, Kab dan Kota Bogor, Subang, Tasikmalaya, Tanjungsari, Sumedang, Tonggeang, Kota Bandung dan Cimahi. Layanan perpustakaan keliling ini juga tidak hanya mengunjungi tempat-tempat ramai, tetapi 
juga sekolahsekolah yang ada di Jawa Barat. Contohnya di SDN 201 Sukaluyu dan SMPN 44 Bandung, sekolah-sekolah tersebut sudah pernah merasakan layanan perpustakaan keliling. Menurut salah satu guru di SDN 201 Sukaluyu, layanan perpustakaan keliling ini memberikan tambahan koleksi buku untuk perpustakaan sekolah dan menarik minat baca para siswa.

Inovasi jemput bola Dispusipda Jawa Barat ini juga mendapatkan penghargaan 99 Top Sinofik oleh Menpan RB. Penghargaan Sinofik ini yakni inovasi yang baru dan belum dilakukan di daerah lainnya. Banyak sekali keberhasilan dengan diadakannya inovasi perpustakaan keliling, yaitu salah satunya para pelajar dapat membaca koleksi-koleksi buku baru yang dikirim oleh perpustakaan keliling ke sekolah mereka dan tingkat minat baca di kalangan pelajar juga dapat terus bertambah. Dengan diadakannya layanan perpustakaan keliling, para pelajar di Jawa Barat dapat mengikuti lomba-lomba yang berkaitan degan literasi. Layanan perpustakaan keliling ini dapat kita nilai kualitas pelayanan yang diberikan dengan menggunakan teori Parasuraman yang mengandung 5 unsur dimensi, yaitu sebagai berikut.

\section{a. Tangibles}

Tangibles adalah adanya bukti fisik seperti sarana dan prasarana yang diberikan. Dalam kasus penelitian program literasi ini, tim peneliti mengambil salah satu contoh dari program literasi yaitu pelayanan perpustakaan keliling. Dalam pelayanan perpustakaan keliling, mereka menyiapkan sarana dan prasarana dalam bentuk mobil yang dapat berpindahpindah dari satu titik layanan ke titik layanan yang lain serta perpustakaan keliling juga menyiapkan koleksi buku untuk menarik para siswa. Mobil perpustakaan keliling ini sudah mengunjungi Kabupaten dan Kota di Jawa Barat, seperti di Kota Bandung yang sudah dikunjungi perpustakaan keliling di 15 titik, di Kabupaten Bandung ada 10 titik, Cimahi 2 titik, Kabupaten Bandung Barat 11titik, Kabupaten Sumedang 4 titik, Kabupaten Sukabumi 1 titik dan Dinas Sosial Provinsi Jawa Barat ada 6 titik.

Dalam mengukur dimensi tangible, tim peneliti melakukan wawancara dan observasi langsung ke sekolah-sekolah yaitu SDN 201 Sukaluyu dan SMPN 44 Bandung. Pihak sekolah SDN 201 Sukaluyu maupun SMPN 44 mengatakan kedatangan pelayanan perpustakaan keliling sangat ditunggutunggu oleh para siswa karena mereka sangat antusias dengan bukubuku yang ada di perpustakaan keliling. Untuk dikunjungi oleh perpustakaan keliling, sarana dan prasarana di sekolah harus memadai, seperti di SDN 201 Sukaluyu dan SMPN 44 Bandung, mereka mempunyai pojok baca di setiap kelas dan itu menjadi poin penting dalam persyaratan untuk dikunjungi oleh perpustakaan keliling karena perpustakaan keliling hanya memberikan fasilitas berupa penambahan koleksi buku, tidak memberikan fasilitas dalam bentuk sarana dan prasarana untuk berlangsungnya kegiatan literasi.

b. Reliability

Pada pelayanan perpustkaan keliling oleh Dispusipda memiliki prosedur yang dimana titik layanan (seperti sekolah, lapas, dll) harus menyerahkan proposal pengajuan terlebih dahulu. Setelah Proposal diterima, dari pihak Dispusipda akan melakukan survey hal ini bertujuan untuk mengetahui apakah sarana dan prasarana nya memadai, karena hal ini akan menyangkut kepada kemampuan dari pihak penyelenggara dalam memberikan layanan. Pihak Dispusipda hanya memberikan estimasi waktu 30 (tiga puluh) menit. 


\section{Gambar 1}

\section{Alur Pelayanan}

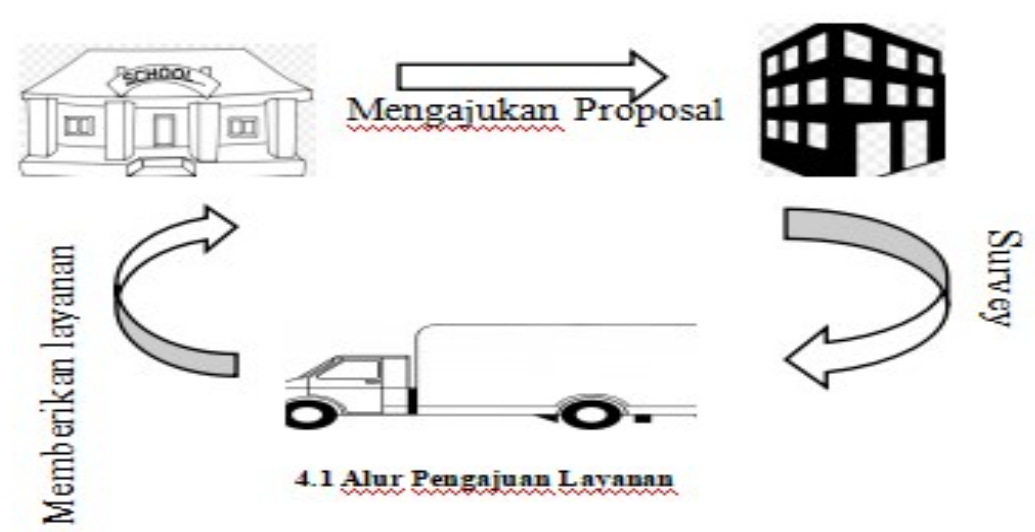

\section{c. Responsiveness}

Daya tanggap dari pemberi layanan perpustakaan keliling sangat responsif, tetapi cukup lama untuk menunggu keputusan dari pihak Dispusipda selaku pihak yang mengelola pelayanan perpustakaan, dikarenakan tahapan yang sudah dijelaskan pada dimensi reliability. Pihak yang mengajukan proposal harus menunggu sampai Dispusipda melakukan survei terhadap sarana dan prasarana yang dimiliki. Setelah melakukan survei dan semua persyaratan terpenuhi, pihak Dispusipda langsung mendatangi tempat yang akan dijadikan titik layanan perpustakaan keliling.

Selain dapat dilihat dari sudut pandang pemberi layanan, dimensi ini juga dapat dilihat dari sudut pandang masyarakat khususnya siswa. Para siswa sangat berantusias setiap kali layanan perpustakaan keliling mengunjungi sekolah mereka. Dengan adanya pelayanan perpustakaan keliling, dapat meningkatkan minat baca para siswa. Meningkatnya minat baca para siswa dapat mendorong pengetahuan dan wawasan mereka serta mereka siap dalam menghadapi bonus demografi. Berikut ini statistik persentase peminjaman buku di Jawa Barat. Dapat dilihat dari statistik tersebut, antusias masyarakat untuk membaca dinilai cukup baik. Dengan pelayanan yang dinilai baik, diharapkan Dispusipda selaku pemberi koleksi buku-buku dapat menambahkan koleksi buku yang uptodate dan bermanfaat pada kalangan siswa agar meningkatkan minat baca para siswa.

\section{Gambar 2}

\section{Peminjaman Buku}

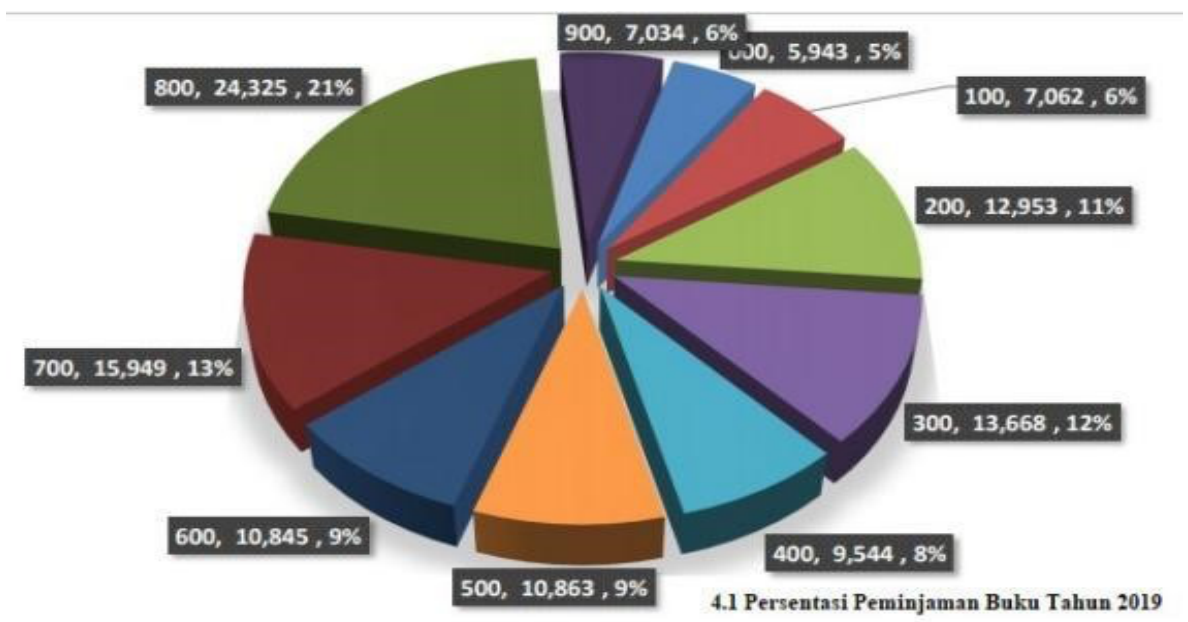




\section{d. Assurance}

Pada dimensi ini ditekankan bahwa pihak memberikan layanan harus bersikap sopan dan santun, selain itu harus mampu menggait titik layanan yang diluar Kota Bandung mampu memberikan layanan kepada masyarakat seperti perpustakaan keliling sendiri. Contohnya Kota Cirebon yang sudah melaksanakan program perputakaan keliling. Ini menandakan bahwa adanya dampak yang sangat signifikan dengan adanya program tersebut dan mampu menciptakan partisipasi pemerintahan daerah di Jawa Barat dalam menciptakan inovasi pelayanan.

\section{e. Empathy}

Yaitu suatu kegiatan memposisikan diri sendiri pada perasaan orang lain. Dalam pelayanan publik berarti pelayanan publik atau pegawai dapat melayani penggunjung dengan baik seperti memberikan senyum, dan dapat membantu pengujung. Dalam empathy ini memiliki sub bab sebagai berikut:

1. Access (Akses), yaitu berhubungan dengan kemudahan pelayanan. Dalam kaitannya dengan program literasi yaitu salah satu pelayanan adalah dengan diadakannya mobil perpustakaan keliling. Mobil perpustakaan keliling tersebut dapat memudahkan akses masyarakat untuk membaca buku. Mobil perpustakaan keliling ini juga menyediakan buku yang beragam sehingga masyarakat dapat meilih buku yang ingin dibaca.

2. Communication (Komunikasi), yaitu kemampuan pihak penyedia jasa untuk selalu menginformasikan sesuatu dalam bahasa yang mudah dimengerti oleh pelanggan dan pihak penyedia jasa selalu mau mendengarkan apa yang disampaikan oleh pelanggan. Dalam hal ini sekolah yang ingin dibantu oleh perpustakaan keliling mengajukan proposal ke Dispusipda Provinsi Jawa Barat. Pengajuan proposal ini bisa langsung datang ke Dispusipda Provinsi Jawa Barat atau dengan mnegirimkan softcopy melalui alamat email Dispusipda Provinsi Jawa Barat. Hal tersebut dapat memberikan kemudahan bagi para pengaju proposal yang memliki jarak agak jauh dari Dispusipda Jawa Barat.

3. Understanding Customer, yaitu usaha untuk mengetahui dan mengenal pelanggan beserta kebutuhankebutuhannya. Setelah pengajuan proposal, pihak dari Dispusipda akan melakukan survei. Survei ini dimaksudkan agar pemberian pelayanan perpustakan keliling ini tepat sasaran. Hal ini selaras dengan yang dituturkan oleh Ibu Teti selaku Pustakawan Dispusipda.

\section{"Siapapun boleh mengajukan proposal untuk dijadikan titik layanan perpustakaan kelilingini, Dispusipda hanya membantu dalam koleksi bukunya saja tidak mencakup sarana dan prasarananya. Jadi jika sudah memberikan proposal, pihak Dispusipda akan survey apakah tempat yang akan dijadikan titik layanan memiliki tempat yang memadai, sarana yang cukup dan adanya koleksi buku. Dalam pelayanan perpustakaan keliling, ada sistem pemberian pinjaman dalam jangka waktu panjang, jika buku tsb sudah tidak dibutuhkan lagi (bosan), mereka dapat menggantinya dengan yang baru."}

Dengan begitu siapa saja dapat mengajukan proposal untuk mendapatkan layanan perpustakaan keliling. Pihak pemohon titik layanan harus memiliki sarana dan prasarana yang memadai dan koleksi buku yang sudah ada, pihak Dispusipda hanya memberikan penambahan koleksi buku saja. 
Dapat dilihat dari teori tersebut bahwa layanan perpustakaan keliling sudah cukup baik, tetapi kekurangannya ketika msyarakat ingin merasakan layanan dari perpustakaan keliling, mereka harus mengajukan proposal terlebih dahulu yang membuat alur layanan menjadi semakin lama. Namun, kelebihan dengan adanya layanan perpustakaan keliling juga sangat banyak. Para pelajar jadi gemar membaca. Dengan meningkatnya minat baca di kalangan pelajar, mereka dapat menumbuhkan budaya literasi dalam dirinya. Budaya literasi juga dapat membentuk karakter suatu bangsa. Karakter yang terbentuk dapat menjadi bekal bagi para pelajar yang berkualitas dan siap untuk bersaing dengan generasi muda yang lainnya. Hal ini menjadi acuan bagi Dispusipda Jawa Barat untuk meningkatkan kualitas pelayanan perpustakaan keliling yang diberikan dan membuat inovas-inovasi baru agar para pelajar tidak bosan untuk meningkatkan kegemaran membaca mereka dan Dispusipda dapat menjadi fasilitator untuk memfasilitasi pendidikan karakter siswa.

\section{Dampak Program Literasi}

Seperti yang dikemukakan oleh Sutarno (2006) perpustakaan keliling adalah perpustakaan yang dapat memberikan layanan berkeliling (mobile) serta mendatangi tempat pemukiman penduduk, tempat kegiatan masyarakat seperti sekolah, kantor kelurahan dan tempat-tempat terpencil lainnya yang belum terjangkau oleh perpustakaan umum (Kurotin, 2010). Dengan adanya pelayanan perpustakaan keliling mampu memberikan dampak yang signifikan kepada masyarakat yang berada di kawasan titik layanan khususnya pada titik layanan yang berada di Sekolah.

Hal ini selaras dengan yang disampaikan Bapak Rukmas I. Gunandi selaku guru di SDN 201 Sukaluyu sebagai berikut.
"Kalau sebelum adanya GLS ini khusunya pada pelayanan Perpustakaan Keliling, anak hanya terfokus pada buku-buku pelajaran dan pemahamannya hanya sampai bukubuku pelajaran tersebut. Tetapi sesudah diterapkannya program ini di sekolah, kita juga menyediakan sarana dan prasarana yang mendukung program perpustakaan keliling seperti membuat pojok baca dan gerobak baca, dampak kepada anaknya pun sangat terasa. Seperti ketika anak bercerita, bahan-bahan dan narasinya sumbernya dari buku-buku yang mereka baca. Seperti ada alumni sekolah ini yang mengikuti lombalomba literasi dan sudah menjuarai tingkat provinsi, itu karena dari membaca."

Hasil wawancara tersebut menunujukkan dengan adanya program literasi ini, wawasan dan pengetahuan anak menjadi lebih luas. Mental anak pun menjadi berkembang berkat membaca. Anak menjadi berani tampil di depan umum, menceritakan pengetahuan dan wawasannya dari membaca tanpa rasa malu ataupun ragu. Dampak dari program literasi ini dapat memengaruhi bonus demografi yang akan terjadi pada tahun 2030-2045. Dengan adanya program literasi ini, kualitas masyarakat khususnya usia produktif dapat meningkat. Sehingga dapat memacu pertumbuhan ekonomi dan dapat memajukan negara serta dapat mempersiapkan generasi muda dalam menyongsong bonus demografi. Sebagaimana yang disampaikan oleh Bapak Rukmas I. Gunandi, sebagai berikut.

\section{"Sangat mendukung sekali. Jika masyarakat memahami program literasi ini dan mulai dipupuk sejak dini, dampak yang akan ditimbulkan juga akan baik dalam mencapai cita-cita Jawa Barat dan menghadapi Bonus Demografi (Indonesia Emas)."}

Hasil wawancara tersebut menunjukan bahwa program literasi berkaitan dengan revolusi mental seperti menumbuhkan etos kerja, berintegritas dan gotong royong. Hal tersebut dapat dijadikan alternatif dalam menghadapi bonus demografi. Strategi yang diakukan dinas 
pendidikan utuk menghadapi bonus demografi selain dengan mengembangkan program literasi salah satunya dengan mengadakan lomba- lomba literasi seperti mendongeng, story-telling, pidato, berpuisi dan sebagainya.

Berdasarkan paparan tersebut di atas, penelitian ini dilakukan untuk mengetahui bagaimana pelayanan Perpustakaan Keliling sebagai sarana Literai mampu membentuk karakter sesuai nilainilai dalam revolusi mental. Penelitian tentang implementasi Gerakan Literasi Sekolah juga pernah dilakukan oleh Wulandari (2017) dengan hasil temuan bahwa implementasi gerakan literasi sekolah ini didukung oleh potensi guru, orangtua dan sekolah. Secara substansi paradigma revolusi mental adalah pandangan baru tentang perubahan besar dalam struktur mental manusia dalam membangun mentalitas baik. Struktur mental manusia terbangun atsa 3 hal. Pertama, cara berfikir; kedua, cara meyakini; ketiga, cara bersikap. Dari tiga tahap itulah mentalitas baik terwujud dalam bentuk perilaku.

Dalam menilai keterkaitan pelayanan perpustakaan keliling dengan revolusi mental menurut nilai-nilai yang terkandung dalam revolusi mental menurut Joko Widodo sebagai berikut.

a) Integritas

Integritas mengandung nilai yang berkaitan dengan sifat jujur, bertanggungjawab, berkarakter dan dapat dipercaya. Dengan budaya literasi yang diterapkan dikalangan generasi muda, para generasi muda khususnya pelajar dapat menumbuhkan karakter yang berkualitas serta berwawasan luas karena banyaknya ilmu dan pengetahuan yang didapatkan ketika ia membaca. Jika budaya literasi terus diterapkan kepada semua generasi, maka revolusi mental akan terbentuk dengan sendirinya karena budaya literasi sudah mengakar didalam dirinya.

b) Etos Kerja

Nilai ini berkaitan dengan daya saing, inovatif dan kreatifitas seseorang. Dengan meningkatkan budaya literasi, generasi muda dapat meningkatkan semangat mereka dalam mencari wawasan dengan membaca buku. Buku buku yang mereka baca nantinya akan meningkatkan kemampuan berfikirnya, sehingga dengan begitu menciptakan inovasi dan kreatifitas seseorang.

c) Gotong royong

Dengan adanya program perpustakaan keliling, menumbuhkan sikap kerjasama serta membangun interaksi di antara pelajar. Pada saat seseorang mendapatkan suatu informasi yang ia temui setelah memebaca buku, menimbulkan adanya keinginan untuk berbagi pengetahuan bersama temanteman nya atau pun orang lain.

\section{Simpulan}

Program literasi di Jawa Barat sudah berjalan cukup baik. Program literasi ini dilandasi oleh Perda Provinsi Jabar No. 17 Tahun 2011 tentang Pemberdayaan Perpustakaan yang didalamnya menyangkut program literasi. Dari banyaknya program literasi yang ada, salah satunya yaitu pelayanan perpustakaan keliling. Layanan perpustakaan keliling ini diharapkan mampu menumbuhkan minat baca masyarakat khususnya pelajar di Jawa Barat guna mendukung bonus demografi yang didalamnya membentuk karakter siswa sesuai dengan konsep revolusi mental yang melipti etos kerja, integritas dan gotong royong. Dengan adanya layanan perpustakaan keliling, sudah ada 7 Kabupaten/Kota yang menjadi titik layanan seperti Kota Bandung, Kabupaten Bandung, Kabupaten Bandung Barat, Cimahi, Kabupaten 
Sumedang, Kabupaten Sukabumi dan Kota Cirebon. Merujuk kepada teori dimensi pelayanan, dapat disimpulkan bahwa pelayanan program literasi khususnya pada pelayanan perpustakaan keliling sudah cukup baik. Namun ada beberapa kendala yang ditemukan, yaitu: 1. SDM yang kurang dalam mengoptimalkan pelayanan ini; 2. Prosedur pengajuan layanan yang belum efisien, karena dianggap masih menyulitkan bagi titik layanan yang ada di luar kota Bandung dan; 3. Anggaran yang terus berkurang setiap tahunnya yang menyebabkan tidak berjalannya program-program secara optimal dan hal ini jugta berdampak pada jumlah SDM yang bertugas memberikan layanan.

\section{Referensi}

Dinas Perpustakaan dan Kearsipan Daerah. (2018). Pedoman Pembudayaan Kegemaran Membaca.

Hayat. (2017). Manajemen Pelayanan Publik. Depok: Rajawali Pers.

Herdiansyah, H. (2013). Wawancara, Observasi, dan Focus Group. Jakarta: Rajawali Pers.

Kristiawan, M. (2015). Telaah Revolusi Mental dan Pendidikan Karakter dalamPembentukkan Sumber Daya Manusia Indonesia yang Pandai dan Berakhlak Mulia. Ta'dib, 18(1), 13-25.

Krueger, R.A. (1994). Focus Group: A Practical Guide for Applied Research (2 ${ }^{\text {nd }}$ ed). Thousand Oaks, CA: Sage Publications.

Kurotin, E. N. (2010). Permasalahan dan Solusi Penarikan Pajak Restoran di Dinas Pendapatan Pengelolaan Keuangan dan Aset Surakarta. Program Studi Diploma III Perpajakan Fakultas Ekonomi Universitas Sebelas Maret Surakarta.

Lupiyadi, R., Hamdani, A. (2006). Manajemen Pemasaran Jasa. Edisi kedua. Jakarta: Salemba Empat.

Miles, M.B \& Huberman A.M. (1984). Analisis Data Kualitatif. Terjemahan oleh Tjetjep Rohendi Rohidi. (1992). Jakarta : Penerbit Universitas Indonesia.

Mulyadi, D. (2018). Studi Kebijakan Publik dan Pelayanan Publik. Bandung: Alfabet.

Mulyasa, H. E. (2015). Revolusi Mental dalam Pendidikan. Jakarta: Rosdakarya

Salam, E. S. (2019). Membangun Budaya Literasi Melalui Mata Kuliah Bahasa Indonesia Sebagai Media Revolusi Mental Generasi Produktif. Didaktika, 11(2), 158. 10.30863/didaktika.v11i2.163.

Sutarno, N.S. (2006). Manajemen Perpustakaan. Jakarta: CV. Sagung Seto.

Umar, M. A. (2018). Bonus Demografi Sebagai Peluang Dan Tantangan Pengelolaan Sumber Daya Alam Di Era Otonomi Daerah. Genta Mulia: Jurnal Ilmiah Pendidikan, 8(2), 9099. http://ejournal.stkipbbm.ac.id/index.php/gm/article/view/121 